\title{
Long Axis to Short Axis Ratio of Breast Masses Pre-Diagnosed as Fibroadenomas on Ultrasonography. Can it Be a Useful Tool in Predicting Malignancy?
}

\author{
Görüntüleme Yöntemleri ile Benign Bulgular Gösteren Fibroadenomlarda Uzun Aks/Kısa Aks \\ Oranları Malignite Tahmini Üzerine Kullanışsı Bir Gereç Olabilir mi?
}

\author{
(1) Ahmet Sürek1, (1) Mustafa Gökhan Ünsal2, (1) Ahmet Cem Dural1, (1) Muhammet Ferhat Çelik33, (1) Halil Fırat Baytekin4, \\ (D) Enis Öztürk5, (1) Selin Kapan6, (1) Halil Alış6 \\ 1 University of Health Sciences, Faculty of Medicine, Bakırköy Dr. Sadi Konuk Training and Research Hospital, Department of General Surgery, Istanbul, \\ Turkey \\ 2Adnan Menderes University, Faculty of Medicine, Department of General Surgery, Aydın, Turkey \\ ${ }^{3}$ Surp PIrgic Armenian Hospital Foundation, Department of General Surgery, Istanbul, Turkey \\ 4 University of Health Sciences, Faculty of Medicine, Bakırköy Dr. Sadi Konuk Training and Research Hospital, Department of Pathology, Istanbul, Turkey \\ 5 University of Health Sciences, Faculty of Medicine, Bakırköy Dr. Sadi Konuk Training and Research Hospital, Department of Radiology, Istanbul, Turkey \\ ${ }^{6}$ Aydin University, Faculty of Medicine, VM Medical Park Florya Hospital, Department of Surgery, Istanbul, Turkey
}

\section{Abstract}

Objectives: The purpose of this study was to calculate the long-axis-to-short axis ratio of breast masses pre-diagnosed as fibroadenoma (FA) on ultrasonography and determine its role in predicting malignancy.

Materials and Methods: Between January 2011 and March 2014, 1,154 patients who underwent tru-cut biopsy for the evaluation of solid breast masses encountered on imaging were evaluated. Of these, patients with breast masses that were diagnosed as FA based on ultrasonographic findings were included ( $n=707)$ into the study. The long axis ratio of lesions with only 1-2 lobulations or had well circumscribed borders, homogenous echogenicity was measured parallel to the skin. The patient's clinical characteristics and demographic data, imaging and pathology findings were reviewed.

Results: Pathology findings revealed malignancy in $13(1.8 \%)$ patients. Two of these were $<40$ years and 11 of them were $>40$ years $(p=0.003)$. The long axis-short axis ratio was 1.8 for the benign cases and 1.4 for the malignant cases. The cut off value of the two ratios was calculated to be 1.4 $(p=0.001)$. Most of the lesions were on right side and upper outer quadrant ( $n=394,55.7 \%$ and $n=389,55 \%$ respectively). The rate of malignancy was similar according to location.

Conclusion: Breast masses diagnosed as FA based on imaging with a long axis to short axis ratio less than 1.4 may be at an increased risk for malignancy despite the presence of benign sonographic features. In patients older than 40 with notable risk factors, a detailed review of pathological findings is strongly encouraged.

Key Words: Fibroadenoma, Benign Breast Mass, Breast Imaging

\section{Öz}

Amaç: Bu çalışmada görüntüleme yöntemleri sonrası fibroadenom (FA) ön tanısı alan meme kitlelerinin uzun ve kısa aks oranlarının hesaplanması ve elde edilen bulguların malignite için prognostik öneminin olup olmadığının araştırılması amaçlanmıştır.

Gereç ve Yöntem: Ocak 2011-Mart 2014 yılları arasında görüntülemede solid lezyon saptanıp tru-cut biyopsi yapılan 1154 hasta değerlendirildi. $\mathrm{Bu}$ hastalardan ultrasonografi değerlendirmesine göre FA olarak tanımlanan hastalar $(n=707)$ çalışmaya dahil edildi. Uzun aks cilde paralel olacak

Address for Correspondence/Yazışma Adresi: Dr. Ahmet Cem Dural

University of Health Sciences, Faculty of Medicine, Bakırköy Dr. Sadi Konuk Training and Research Hospital, Department of General Surgery, Istanbul, Turkey

Phone: +90 5334942969 E-mail: cemdural@hotmail.com ORCID ID: orcid.org/0000-0003-3479-725X

Received/Geliş Tarihi: 08.10.2018 Accepted/Kabul Tarihi: 22.01.2019

๑Copyright 2019 Ankara University Faculty of Medicine

Journal of Ankara University Faculty of Medicine is published by Galenos Publishing House.

All content are under CC BY-NC-ND license. 
şekilde sadece bir veya iki lobulasyonu olan ya da düzgün sınırlı, homojen ekojenitesi olan lezyonlarda ölçüldü. Hastaların demografik verileri, klinik özellikleri, görüntüleme ve patoloji sonuçları değerlendirildi.

Bulgular: Hastaların 13'ünde $(\% 1,8)$ patoloji sonucu malignite ile uyumlu olarak sonuçlandı. Bunlardan ikisi $<40$ yaş olup 11 'i $>40$ yaş idi ( $p=0,003$ ). Uzun aks/kısa aks oranı benign olgularda 1,8 iken malign olgularda 1,4 idi. Bu iki oran arası eşik değer 1,4 olarak ölçüldü ( $p=0,001$ ). Lezyonlar çoğunlukla sağ tarafta ve üst dış kadran ( $n=394, \% 55,7$ ve $n=389, \% 55$, sırası ile) yerleşimli idi. Lokalizasyona göre malignite oranı benzer idi.

Sonuç: Görüntüleme yöntemleri sonrası FA ön tanısı alan smeme kitleleri sonografik olarak benign özellikler gösterse de uzun aks/kısa aks oranının eşik değeri 1,4'ten küçük ise malignite oranı artabilir. Bu hastalarda 40 yaş üstü ve risk faktörü de mevcutsa detaylı patolojik incelemenin göz ardı edilmemesi gerektiğini düşünmekteyiz.

Anahtar Kelimeler: Fibroadenom, Selim Meme Kitlesi, Meme Görüntülemesi

\section{Introduction}

Fibroadenoma (FA) of the breast is the most commonly seen benign solid tumor among all breast masses (1). The exact etiology of FAs is unknown but described as imaginary breast tumors that occur as a result of lobular hyperplasia and distortion. Generally seen in young females less than 30 years of age, they can be encountered in patients from all age groups $(1,2)$. They generally do not demonstrate pre-malignant characteristics and as such regarded as non-life threatening.

Diagnosis of FAs is often based on history, physical examination and imaging findings. About 55\% of all FAs are located in the left breast with the most common location being the upper outer quadrant of the left breast $(3,4)$. Although the known risk of malignancy is notably low, 65\% of the reported cases appear to be lobular carcinoma (5). This risk varies according to the characteristics of FAs and surrounding epithelial tissue in all age groups. There is still no consensus in the literature regarding the management of FAs and change in size of FAs during their follow-up. Follow-up with serial imaging, biopsy of the mass and surgical removal are among the suggested management protocols (6-8). Pathology results of about $40-50 \%$ of all breast biopsies are reported as FAs (9). Previous studies have noted a slight increase in the risk of malignancy in masses reported as FAs on final pathology $(10,11)$. Compared to the normal population, it is observed that there is an increase in risk of malignancy up to 1.9 times in patients with FA (12). Furhermore, Dupont et al. documented a 2.17 times increase in malignancy risk in patients with FA when compared with healthy cohorts (11). This risk was found to be 3.10 times higher among patients with complex FAs and 3.88 times higher in those with benign proliferative disease. In FA patients with a positive family history, the risk of developing breast cancer was reported to be 3.72 times higher.

On ultrasonography (USG), FAs are well circumscribed, oval shaped masses with homo echogenic properties (1). While small sized FAs are oval or round in shape, they show lobulation as they grow in size. An oval or round lesion is usually thought to be $98 \%$ benign. The transverse axis of FAs is usually greater than that of the anterior-posterior axis. Malignant masses are generally more echogenic when compared to benign lesions, and less echogenic when compared to the surrounding fatty tissue. As these masses grow in size, the homogenic structures can appear heterogeneous due to the presence of necrotic regions.

In our study, we calculated the long to short axis ratios of masses prediagnosed as FA on USG and determined if these findings had a prognostic role in the prediction of malignancy.

\section{Materials and Methods}

This is a retrospective study conducted on 1.988 patients who underwent tru-cut biopsy for solid lesions encountered on imaging studies in their outpatient clinic visits were evaluated. Those with a prediagnosis of FA, a positive family history and patients who had new lesions or whose lesions showed a growth in size during follow-up were included into the study. Exclusion criteria were: Tru-cut biopsy at a clinical setting out of our hospital, incomplete follow-up data, Breast Imaging-Reporting and Data System 4 and 5 mammography category and absence of notable risk factors.

All data including patient demographics, imaging findings, localization of masses, long axis to short axis ratio on imaging and pathology findings were anonymously entered into a digital spreadsheet (Excel ${ }^{\circledR}$ 2007; Microsoft, Redmont, WA, USA). All imaging findings were evaluated by a single radiologist. Ethical approval for this study was obtained from the local ethics commitee (Ethical approval number: 2014/09/26). A written informed consent for tru-cut biopsy was obtained from all patients. Samples were classified according to the World Health Organization's classification criteria. This manuscript was prepared in accordance with STROBE guidelines for case control studies.

Biopsies were performed by an experienced radiologist specializing in breast imaging. Lesions were evaluated on multiple occasions before all invasive procedures were performed. The long axis ratio of non-lobulated breast masses or those described as having only 1-2 lobulations or well circumscribed borders, homogenous echogenicity was measured parallel to the skin. This measurement was used to verify the prediagnosis of FA. All procedures were performed with the same ultrasound device (General Electrics Logiq 9; GE Medical Systems, WI, USA) by using a $12 \mathrm{MHz}$ ultrasound matrix probe. 
Under USG guidance, lesions were entered by using a 14 gauge biopsy needle. After ensuring appropriate needle placement, the needle was fired and tissue samples were retrieved accordingly. Appropriate tissue samples (1-2 cm sized, at least 3 samples) were acquired and fixation was achieved with formaldehyde solution. Biopsy samples of all masses previously diagnosed as FA were stained with routine Hematoxylin \& Eozin (HCtE) stains, evaluated under microscopic view and classified under respective histopathological groups. Samples of all subjects included into this study were classified according to the histopathological findings.

\section{Statistical Analysis}

Statistical analysis was performed by using the $\mathrm{JMP}^{\circledR}$ software version 10.0.0 (SAS ${ }^{\circledR}$, Cary, NC). Parametric variables are represented as mean \pm standard deviation. Categorical variables as numbers and percentages. The Student's $t$ and chisquare tests were used for the comparison of non-categorical and categorical variables respectively. Mann-Whittney $U$ test was used for the evaluation of non-parametric variables. Statistical significance was accepted at $p$ values less than 0.05 .

\section{Results}

The median age of all 707 patients enrolled into the study was 39 years; range (15-84 years). There were 325 patients who were $<40$ years and 382 of the patients were $>40$ years (Figure 1). Pathology findings revealed malignancy in 13 (1.8\%) patients. Of these, two were $<40$ years while 11 were $>40$ years. The risk of malignancy was found to be higher in the group with age $>40$ years $(p=0.003)$ (Table 1$)$.

When the long-axis-to-short axis (LATSA) ratio of FA masses were compared regarding their final histopathology after surgical removal. Benign breast masses prediagnosed as FA on USG imaging were found to have a lower LATSA ratio (1.4) and in patients whose breast masses prediagnosed as FA on USG and a higher LATSA ratio (1.8) were diagnosed as malignant breast masses (Table 2). When both ratios where compared between benign and malignant cases, the ratio was found to be high in the malignant cases $(p=0.001)$.

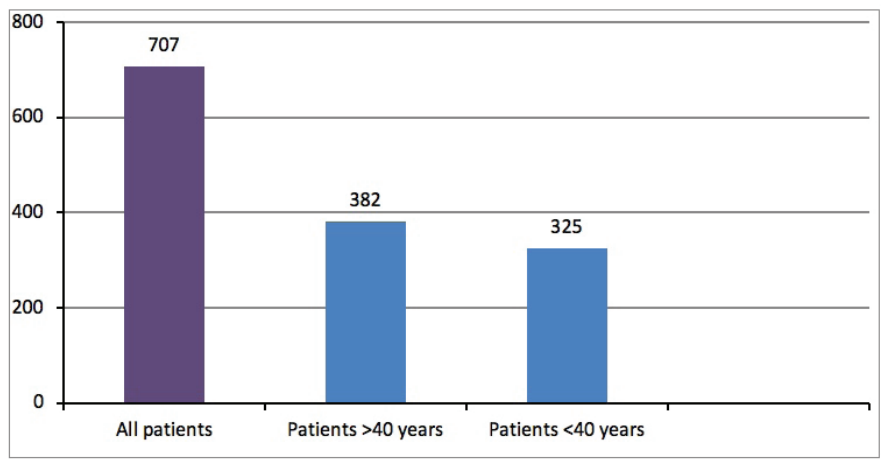

Figure 1: Distribution of patients by age
By location, 375 of the benign lesions were found in the right breast and 319 in the left breast. Nine of the malignant lesions were found in the right beast and 4 in the left breast (Table 3). According to quadrant location of the masses; majority of the lesions (55\%) were located in upper outer quadrant $(n=389)$. In addition, the higher malignancy rate (6.1\%) was in centrally located masses (Table 4). Pathological findings of all malignant cases revealed invasive ductal carcinoma in 11, invasive lobular carcinoma in 1 and malignant epithelial tumor in 1 (Figure 2).

\section{Discussion}

Fibroadenomas are estrogen sensitive, slow growing benign tumors of the breast that usually occur after puberty among young females who are generally younger than 25-30 years. However, they can be seen in females of all age ranges. The incidence of FAs in postmenopausal women $>50$ years is around $5 \%$. In $10-20 \%$ of the cases there can be more than one mass in both breasts. The size of FAs are known to increase during pregnancy and lactation and decrease after menopause. The size

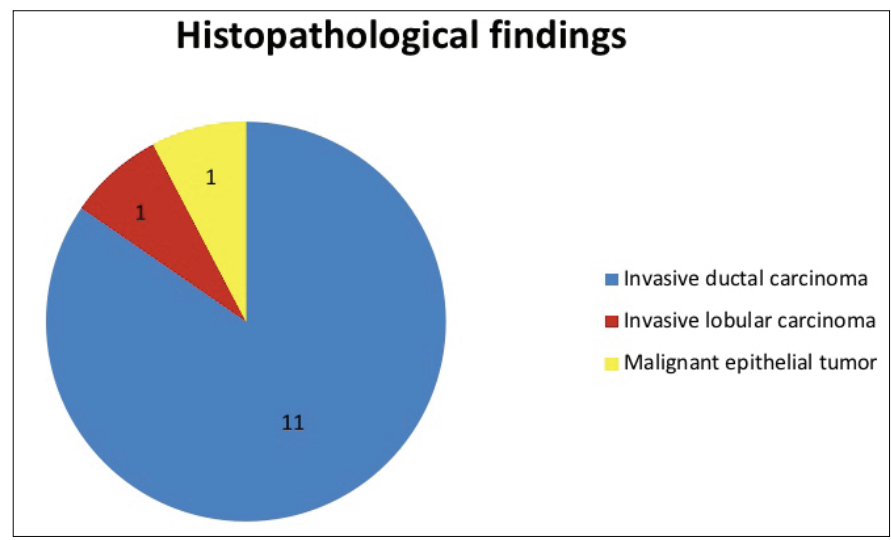

Figure 2: Histopathologic findings in malignant patients

Table 1: Malignancy rates in all patients, patients under 40 and upper 40 years of age $(p=0.003)$

\begin{tabular}{llll} 
Parameter & $\begin{array}{l}\text { Benign } \\
\text { (n/\%) }\end{array}$ & $\begin{array}{l}\text { Malignant } \\
\text { (n/\%) }\end{array}$ & $\begin{array}{l}\text { Total } \\
\text { (n) }\end{array}$ \\
\hline All patients & $694 / 98.2$ & $13 / 1.8$ & 707 \\
\hline Patients under 40 years of age & $314 / 96.6$ & $11 / 3.4$ & 325 \\
\hline Patients upper 40 years of age & $380 / 99.5$ & $2 / 0.5$ & 382
\end{tabular}

Table 2. Long-Axis-To-Short Axis Ratio in patients with benign and malignant histopathology $(\mathrm{p}=0.001)$

\begin{tabular}{lll} 
Parameter & Benign & Malignant \\
Patients $(\mathrm{n} / \%)$ & $694 / 98.2$ & $13 / 1.8$ \\
\hline Mean age (years) & $39.06 \pm 4.1$ & $52.46 \pm 6.2$ \\
LATSA $^{*}$ ratio & $1.4 \pm 0.3$ & $1.8 \pm 0.5$
\end{tabular}

*LATSA: Long-axis to short-axis 
is usually less than $3 \mathrm{~cm}$ and lesions greater than $4 \mathrm{~cm}$ are seen in patients who are 20 years and younger. These are described as adolescent large FAs (13-15). Only $1.5 \%$ of breast masses seen in women $>50$ years are diagnosed as FAs (16).

The diagnosis of FA involves physical examination, imaging and biopsy. Diagnosis with physical examination only is not enough even if the patient is very young. In young females $(<30$ years) USG should be used in combination with the protocols above while USG and mammography should be used in older women $(1,17,18)$. Previous studies have reported a false positive rate of approximately $50 \%$ in cases diagnosed as FA based on physical examination only (19).

There is a lack of consensus regarding the management of these masses. Suggested theories include excision of the mass or periodic follow-up with serial imaging. Although, excision of the mass seems to be a better option for treatment, removal of salient lesions may result in undesirable cosmetic results (16). Previous studies have confirmed FAs as non-premalignant lesions within all age groups $(20,21)$ and are therefore described as a non-risk factor for malignancy. However, there have been studies reporting conflicting findings $(21,22)$. In a large serie published by Levi et al. the risk of developing cancer among patients followed up for a long-term was 1\% in 5 years, 2\% in 12 years (23). The development of malignancy is reportedly low and if present the most commonly encountered malignancy sub-type is lobular carcinoma (14). The degree of risk varies according to the FA characteristics and surrounding epithelial tissue. The risk of malignancy is high in complex FAs that are described as those with the presence of proliferative changes in surrounding epithelial tissue, papillary apocrine changes and epithelial calcifications (11).

On the contrary, large studies have showed that, atypical hyperplasia in FAs do not pose a risk for the development of malignancy. Dupont et al. (11). defined FAs greater than 3 $\mathrm{mm}$, with larger cysts, sclerosing adenosis, papillary apocrine,

\begin{tabular}{|c|c|c|}
\hline Side & Benign (n/\%) & Malignant (n/\%) \\
\hline Right & $375 / 97.7$ & $9 / 2.3$ \\
\hline Left & $319 / 98.8$ & $4 / 1.2$ \\
\hline
\end{tabular}

\begin{tabular}{lll|}
$\begin{array}{l}\text { Table 4: Distribution of benign and malignant lesions by } \\
\text { localization }\end{array}$ & Benign (n/\%) & Malignant (n/\%) \\
\hline Quadrant & $386 / 99.3$ & $3 / 0.7$ \\
\hline Upper outer & $120 / 96.8$ & $4 / 3.2$ \\
\hline Upper inner & $104 / 98.1$ & $2 / 1.9$ \\
\hline Lower outer & $38 / 97.5$ & $1 / 2.5$ \\
\hline Lower inner & $46 / 93.9$ & $3 / 6.1$ \\
\hline Central & &
\end{tabular}

epithelial calcification as complex FAs. They classified samples as proliferative disease; atypical proliferative disease and atypical hyperplastic proliferative disease (11). According to classification, the risk of developing cancer in FAs increases from 1.49 to 7.29 times.

In the literature, FAs are reported to be localized in the left breast (13). Differently, in our study the majority of FAs (54\%) were located in the right breast. But similarily, the majority of FAs (55\%) in our study were located in the upper outer quadrant as reported in the literature (13).

Malignant masses are usually echogenic when compared to benign lesions and less echogenic when compared to the surrounding fatty tissue $(15,25)$. A closer look at the benign and malignant characteristics of solid breast masses on USG show that, benign lesions are oval, round in shape and well circumscribed with a LATSA ratio $>1.4$. They are characterized by a border shadow and an increase in posterior echo. Malignant masses on the other hand are distorted in shape and multilobulated. The borders are spiky, non-uniform with a LATSA ratio < 1.4 and characterized by decreased posterior echo and absent border shadow $(15,25)$. A study by Stavros et al. that investigated the ultrasonographic features of solid breast masses revealed that, the long axis (transverse axis)/short axis (anteriorposterior axis) ratio could have an effect on malignancy. (15) The authors concluded that, masses with a shorter long axis had a greater risk of malignancy.

In another study by Malik et al., USG images were evaluated in 56 young females and 49 of these had benign findings, 2 patients were malignant and 5 patients were evaluated as intermediate and histopathological findings revealed that 53 of the lesions were benign and 3 lesions were malignant. (26) Two of the three malignant masses were found to have a LATSA ratio of $<1.4$ (26). Similarly, findings from our study revealed that a LATSA ratio of $<1.4$ of lesions that were reported as malignant on final histopathological examination.

Among the known risk factors for breast cancer, older age is regarded as an important risk factor for the development of breast malignancy (27). The rate of breast cancer is known to be lower in female subjects less than 20 years. The observed risk is known to increase steadily among female subjects after the age of 30 until menopause. However, this risk has been reported to increase enormously after menopause. In a study of females subjects who have been previously diagnosed with breast cancer, $70 \%$ of the patients were found to be $>50$ years. The incidence of breast cancer in these patients was also reported to be 4 times higher than patients who were younger than 50 years (28). In another study; a worse prognosis was associated with younger age. Our study however documented 11 patients who were $>40$ years out of the 13 patients whose pathological findings were consistent with malignancy. The calculated mean 
age of these patients was 55.4 years and thus in agreement with what has been reported in the literature.

In conclusion, our study is the first study to investigate the relationship between the LATSA ratio of FA diagnosed on imaging and potential for malignancy. Our findings showed that, in FAs the axis ratio might be a useful predictor for predicting malignancy. Future studies enrolling a larger number of patients may be required to confirm our preliminary findings.

\section{Ethics}

Ethics Committee Approval: Bakırkoy Dr. Sadi Konuk Training and Research Hospital Ethical Committee for Clinical Research (Nr: 2014/09/26).

Informed Consent: A written consent was obtained from all patients.

Peer-review: Externally peer-reviewed.

\section{Authorship Contributions}

Surgical and Medical Practices: A.S., M.G.Ü., E.Ö., H.F.B., Concept: A.S., M.F.Ç., A.C.D., H.A., Design: M.G.Ü., A.S., M.F.Ç., S.K., Data Collection or Processing: A.S., H.F.B., E.Ö., Analysis or Interpretation: S.K., H.A., A.C.D., Literature Search: A.C.D., H.F.B., Writing: A.S., M.G.Ü.

Conflict of Interest: No conflict of interest was declared by the authors.

Financial Disclosure: The authors declared that this study received no financial support.

\section{References}

1. Amin AL, Purdy AC, Mattingly JD, et al. Benign breast disease. Surg Clin North Am. 2013;93:299-308.

2. Jayasinghe $Y$, Simmons PS. Fibroadenomas in adolescence. Curr Opin Obstet Gynecol. 2009;21:402-406.

3. Rosen PP. Fibroepithelial lesions. Rosen's Breast Pathology. 2nd ed. Philadelphia: Lippincott Williams \& Wilkins; 2001;p.163-200.

4. Kuijper $A$, Mommers $E C$, van der Wall $E$, et al. Histopathology of fibroadenoma of the breast. Am J Clin Pathol. 2001;115:736-742.

5. Malt RA. Morris PJ. Benign condition of breast. Oxford Textbook of Surgery. New York: Oxford University Press. 1994;p.796-799.

6. Bland KI, Copeland EM. The Breast. 4th ed. Philadelphia: Saunders; 2009.

7. Sikora K. Genes, dreams and cancer. BMJ. 1994;308:1217-1221.
8. Moy L, Heller SL, Bailey L, et al. ACR Appropriateness Criteria ${ }^{\circledR}$ Palpable Breast Masses. J Am Coll Radiol. 2017 May;14(5S):S203-S224.

9. Greenberg R, Skornick Y, Kaplan 0. Management of breast fibroadeomas. J Gen Intern Med. 1998;13: 640-645.

10. Dixon JM . Cystic disease and fibroadenoma of the breast: natural history and relation to breast cancer risk. Br Med Bull. 1991;47:258-271.

11. Dupont WD, Page DL, Parl FF et al. Long-term risk of breast cancer in women with fibroadenoma. N Engl J Med. 1994; 331:10-15

12. Markopoulos C, Kouskos E, Mantas D, et al. Fibroadenomas of the breast: is there any association with breast cancer? Eur J Gynaecol Oncol. 2004;25:495-497.

13. Rosen PR. Rosen's Breast Pathology. 3nd ed. Philadelphia: Lippincott Williams \& Wilkins 2009; p.1-32.

14. Heywang-Kobrunner SH. Diagnostic Breast Imaging. 2nd ed. New York: Thieme, 2001;p.162-208.

15. Stavros AT, Thickman $D$, Rapp $C L$, et al. Solid breast nodules: use of sonography to distinguish between benign and malignant lesions. Radiology. 1995;196:123-134.

16. Dewitt JE. Benign disorders of the breast in older women. Surg Gynecol Obstet. 1986;162:340-342.

17. Mansel RE, Webster DJT, Sweetland HM et al. Fibroadenoma and related tumors. Benign Disorders and Diseases of the Breast. 3rd ed. Edinburgh: Saunders. 2009;p.81-106.

18. Jonhson AT, Henry-Tillman RS, Smith LF, et al. Percutaneous excisional breast biopsy. Am J Surg. 2002;184:550-554.

19. Trapido EJ, Brinton LA, Schairer C, et al. Estrogen replacement therapy and benign breast disease. J Natl Cancer Inst. 1984;73:1101-1105.

20. $\mathrm{Yu} H$, Rohan $T E$, Cook MG, et al. Risk factors for fibroadenoma: a casecontrol study in Australia. Am J Epidemiol. 1992;135:247-258.

21. Hindle $\mathrm{WH}$, Alonzo L. Conservative management of breast fibroadenomas. Am J Obstet Gynecol. 1991;164:1647-1650.

22. McDivitt RW, Stevens JA, Lee NC, et al. Histologic types of benign breast disease and the risk for breast cancer. The Cancer and Steroid Hormone Study Group. Cancer. 1992;69:1408-1414.

23. Levi F, Randimbison $L$, Te VC, et al. Incidence of breast cancer in women with fibroadenoma. Int J Cancer. 1994;57:681-683.

24. Cant PJ, Madden MV, Coleman MG, et al. Non-operative management of breast masses diagnosed as fibroadenoma. Br J Surg. 1995;82:792-794.

25. American College of Radiology. Breast Imaging Reporting and Data System, Breast Imaging Atlas. First ed. Reston, VA:American College of Radiology;2003.

26. Malik G, Waqar F, Buledi GQ. Sonomammography for evaluation of solid breast masses in young patients. J Ayub Med Coll Abbottabad. 2006;18:3437.

27. Clavel-Chapelon F, Gerber M. Reproductive factors and breast cancer risk. Do they differ according to age at diagnosis? Breast Cancer Res Treat. 2002;72:107-115.

28. Rogers C, Thompson K, Robinson S. Intoducing A Breast Health Strategy into Schools. Health Education 2002;12:106-112. 